\title{
Variation morphogeometrics of Africanized honey bees (Apis mellifera) in Brazil
}

\author{
Lorena A. Nunes ${ }^{1}$, Edilson D. de Araújo ${ }^{2}$, Luis C. Marchini ${ }^{1} \&$ Augusta C. de C. C. Moreti ${ }^{1}$
} 1. Escola Superior de Agricultura "Luiz de Queiroz"- ESALQ/USP, Departamento de Entomologia e Acarologia, Laboratório de Apicultura. Av. Pádua Dias, 11, 13418-900 Piracicaba, SP,
Brazil. (lorenunes1@yahoo.com.br; lcmarc@usp.br; acmoreti@iz.sp.gov.br)
2. Universidade Federal de Sergipe, Campus Universitário José Aloízio de Campos, Departamento de Biologia, Laboratório de Genética e Conservação de Recursos Naturais - GECON.
Av. Marechal Rondon, s/n, 499100-000 São Cristóvão, SE, Brazil. (edaraujo@yahoo.com.br)

\begin{abstract}
RESUMO. Variação morfogeométrica das abelhas africanizadas (Apis mellifera) no Brasil. Apis mellifera L., 1758 têm sido alvo de muitos estudos morfométricos principalmente pela sua importância ecológica, pela sua grande capacidade de adaptação, sua ampla distribuição e por serem capazes de se estabelecer eficientemente em diversas regiões. O presente trabalho teve como objetivo estudar as variações da forma em asas e corbículas de operárias de Apis mellifera scutellata Lepeletier, 1836 provenientes das cinco regiões biogeográficas do Brasil utilizando análises morfogeométricas, a fim de verificar a existência de padrões de variação de forma e tamanho das abelhas africanizadas no Brasil após 16 anos do estudo clássico realizado com esta espécie, possibilitando uma análise espaço-temporal comparativa utilizando recursos tecnológicos atuais para a avaliação de dados morfométricos. Foi realizada uma amostragem em 14 localidades no Brasil, abrangendo as cinco regiões geográficas. A partir de análise de forma e análises multivariadas verificou-se que a forma da asa revelou um padrão geográfico entre as populações de Apis mellifera no Brasil. As variações geográficas podem ser atribuídas à grande extensão territorial do Brasil, além de poder estar associada à diferenças entre ecorregiões.
\end{abstract}

PALAVRAS-CHAVE. Distribuição populacional, forma, asa, corbícula.

\begin{abstract}
The morphometrics of the honey bee Apis mellifera L., 1758 has been widely studied mainly because this species has great ecological importance, high adaptation capacity, wide distribution and capacity to effectively adapt to different regions. The current study aimed to investigate the morphometric variations of wings and pollen baskets of honey bees Apis mellifera scutellata Lepeletier, 1836 from the five regions in Brazil. We used geometric morphometrics to identify the existence of patterns of variations of shape and size in Africanized honey bees in Brazil 16 years after the classic study with this species, allowing a temporal and spatial comparative analysis using new technological resources to assess morphometrical data. Samples were collected in 14 locations in Brazil, covering the five geographical regions of the country. The shape analysis and multivariate analyses of the wing allowed to observe that there is a geographical pattern among the population of Apis mellifera in Brazil. The geographical variations may be attributed to the large territorial extension of the country in addition to the differences between the bioregions.
\end{abstract}

KEYWORDS. Population distribution, shape, wing, pollen basket.

Many races and subspecies of Apis mellifera occur in a wide range of natural distribution, and differ from one another in many behavioral and morphological features (ToFILSKI, 2008). The African subspecies (Apis mellifera scutellata Lepeletier, 1836) has colonized South, Central and North America, since its introduction in Brazil in 1956. During the colonization process in the Americas, the bees were subjected to several evolutionary forces including the natural and artificial selection (Michener, 1975; RAtNiEKs, 1991; Diniz-Filho \& Malaspina, 1995). Furthermore, the A. mellifera has bred with European bees introduced in Brazil by the Jesuit priests since the $19^{\text {th }}$ century. The resulting species are currently known as the Africanized bees and are more similar to the African bees than to the European species, in terms of morphology, biochemistry, cuticular hydrocarbonates, allelic frequency and isoemzymes (Diniz-Filho \& Malaspina, 1995).

The similar environmental conditions between Brazil and Africa have greatly facilitated the adaptation of African honey bees to Brazil in addition to the capacity of the African subspecies to imprint some adaptive advantages to the offspring, ensuring the expansion of the Africanized honey bee throughout the Americas (Garcia \& Couto, 2005).
The wide geographical distribution and environmental heterogeneity in the American continent and the differences among species of the Africanized bees may help to better understand the micro-evolutionary processes involving population differentiation. Furthermore, stochastic processes, genetic drift and migration, mainly in morphologic and behavioral terms and physiological adaptations to the distinct local conditions contribute to differentiating populations (DinIz-FilHo et al., 2000).

Several studies have been carried out on Apis mellifera to differentiate subspecies regarding geometric morphometrical features, using programs of automatic identification (Francoy et al., 2006, 2008; TOFILSKI, 2008). This species is described as an example of a bee species endowed with important features, such as fast development and adaptation, rusticity, high capacity for honey and propolis production, better capacity for food source identification, efficient pollinating features and disease resistance (GONÇALVES, 2006).

Morphometrics involves a group of techniques that allow to deduct evolutionary processes from spatial standards and to test these theories to explain the "Africanization" of Apis mellifera populations in the Neotropical region (Diniz-Filho \& Malaspina, 1995), 
particularly, the geometric morphometrics that analyzes the wing morphometry to provide information for the identification of honeybee populations (TOFILSKY, 2008).

The geometric morphometrics allows a strict analysis of the morphometrical variation of a given structure in organisms of several sizes using, mainly, methods of multivariate statistics. The most common use of morphometrics consists of identifying configurations of anatomical marks in the several morphological features (KLINGENBERG, 2002).

This technique is suitable, fast and less costly, besides the anatomical marks allow to identify morphometrical variations between the homologous morphological structure in different organisms (FRANCOY et al., 2008; Francoy \& ImPERATIZ-FonseCA, 2010) and are more accessible to apiarists (ToFILSKY, 2008).

This technique has been successfully used in evolutionary biology (such as geographic, seasonal and population variations), physical anthropology, paleontology and systematic (BITNER-MathÉ et al., 1995; Monteiro et al. 2002; Friess \& Baylac, 2003; Pretorius, 2005; Shipunov \& Bateman, 2005; Nunes et al., 2008).

Diniz-Filho \& Malaspina (1995) studied spatial structure using conventional morphometrics to investigate the distribution of the Africanized bee in Brazil and observed population variations. However, in the 1990s, the technique of geometric morphometrics were still not available and the conventional morphometrics allows to individuate adequately size variations, but not shape variations (TofiLSKY, 2008). Therefore, this study aimed to investigate shape variations in wings and pollen baskets of honey bees Apis mellifera scutellata of five regions in Brazil. We used geometric morphometrics to verify the existence of variation patterns of shape and size of Africanized honey bees in Brazil 16 years after the classic study performed by Diniz-Filho \& Malaspina (1995), allowing a temporal and spatial comparative analysis using new technological resources to assess morphometrical data.

\section{MATERIAL AND METHODS}

The study was conducted in two years - from April 2009 to April 2011. Fourteen locations in 13 municipalities in Brazil were sampled: Cassilândia and Aquidauana, state of Mato Grosso do Sul; Fortaleza and Itapiúna, state of Ceará; Riachuelo and Pacatuba, state of Sergipe; União Vitória, Maringá and Ubiratã, state of Paraná; Rolim de Moura, state of Rondônia; Erval Seco, state of Rio Grande do Sul; Rio Claro and Piracicaba, state of São Paulo (Tab. I), covering the five regions of the country. In each location, 20 hives from apiaries were sampled and 10 individuals per hive were collected totaling 200 individuals per municipality and 1,400 altogether.

Morphometrical study. Front wings and right pollen baskets were removed from each individual with a fine point tweezers. Afterwards, they were placed between two blades to keep the structures flat for capturing the image and later measurements.

The images were obtained and digitalized through a camera coupled to the stereomicroscopy using the Leica Application suite version 3.4.1. From the images of the wings and pollen baskets, anatomical points were marked using the software TpsDIG2, version 1.40 (RoHLF, 1998) (Figs 1, 2).

The morphometrical analyses were performed using features of the wings and pollen baskets, given that the shape and size of the pollen baskets relate to pollen production and propolis transport, while the length and width of the wings are related to the capacity to fly (Souza et al., 2009).

Bee wings are extension of the exoskeleton adapted to fly (Winston, 2003), and are the most important means of locomotion for the bees. The pollen basket has great ecological importance, given that they result from changes in the tibia of the third pair of legs, becoming very large and slight concave in the inner face, with hairs of varied lengths and shapes located on the side. The tibia acquired similarity to a basket where the pollen is stored in the shape of small balls (THORP, 1979).

Tab. I. Sampling sites, geographic coordinates and sampling region of the populations of Apis mellifera L., 1758.

\begin{tabular}{|c|c|c|}
\hline Locations & Coordinates & Brazilian Region \\
\hline Cassilândia, MS & $19^{\circ} 06^{\prime} 46^{\prime \prime S}, 51^{\circ} 44^{\prime} 02^{\prime \prime} \mathrm{W}$ & Central-west \\
\hline Fortaleza, CE & $03^{\circ} 43^{\prime} 01^{\prime \prime} \mathrm{S}, 38^{\circ} 32^{\prime} 34^{\prime \prime} \mathrm{W}$ & Northeast \\
\hline Itapiúna, CE & $04^{\circ} 33^{\prime} 50^{\prime \prime} \mathrm{S}, 38^{\circ} 55^{\prime} 19^{\prime \prime} \mathrm{W}$ & Northeast \\
\hline União da Vitória, PR & $26^{\circ} 13^{\prime} 48^{\prime \prime} \mathrm{S}, 51^{\circ} 05^{\prime} 09^{\prime \prime} \mathrm{W}$ & South \\
\hline Maringá, PR & $23^{\circ} 25^{\prime} 30^{\prime \prime} \mathrm{S}, 51^{\circ} 56^{\prime} 20^{\prime \prime} \mathrm{W}$ & South \\
\hline Aquidauana, MS & $20^{\circ} 28^{\prime} 15^{\prime \prime} \mathrm{S}, 55^{\circ} 47^{\prime} 13^{\prime \prime} \mathrm{W}$ & Central-west \\
\hline Rolim de Moura, RO & $11^{\circ} 43^{\prime} 31^{\prime \prime} \mathrm{S}, 61^{\circ} 46^{\prime} 40^{\prime \prime} \mathrm{W}$ & North \\
\hline Riachuelo, SE & $10^{\circ} 43^{\prime} 40^{\prime \prime} \mathrm{S}, 37^{\circ} 11^{\prime} 13^{\prime \prime} \mathrm{W}$ & Northeast \\
\hline Pacatuba, SE & $10^{\circ} 27^{\prime} 10^{\prime \prime} \mathrm{S}, 36^{\circ} 39^{\prime} 03^{\prime \prime} \mathrm{W}$ & Northeast \\
\hline Erval Seco, RS & $27^{\circ} 32^{\prime} 56^{\prime \prime} \mathrm{S}, 53^{\circ} 30^{\prime} 14^{\prime \prime} \mathrm{W}$ & South \\
\hline Ubiratã, PR & $24^{\circ} 32^{\prime} 42^{\prime \prime} \mathrm{S}, 52^{\circ} 59^{\prime} 16^{\prime \prime} \mathrm{W}$ & South \\
\hline Rio Claro, SP & $22^{\circ} 24^{\prime} 39^{\prime \prime} \mathrm{S}, 47^{\circ} 33^{\prime} 39^{\prime \prime} \mathrm{W}$ & Southeast \\
\hline Piracicaba, SP & $22^{\circ} 43^{\prime} 30^{\prime \prime} \mathrm{S}, 47^{\circ} 38^{\prime} 56^{\prime \prime} \mathrm{W}$ & Southeast \\
\hline
\end{tabular}




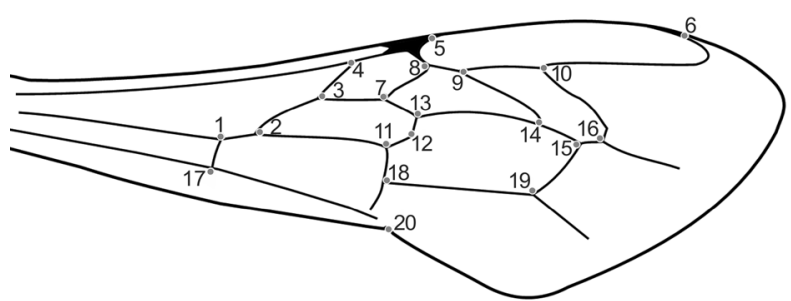

Fig. 1. Structure of front wing of Apis mellifera with anatomical marks used in the analyses.

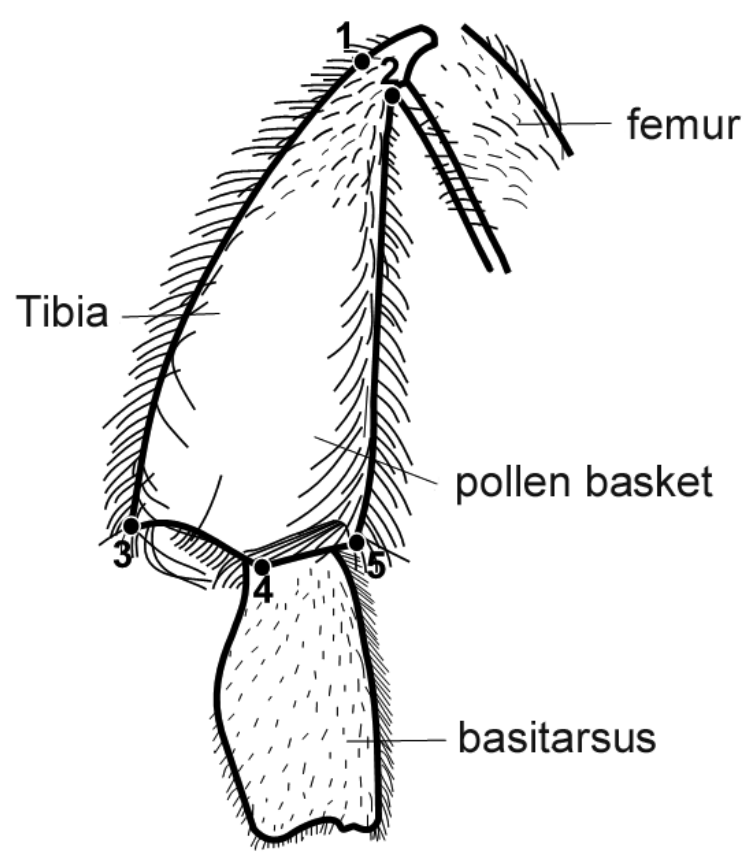

Fig. 2. Structure of a right pollen basket of Apis mellifera with anatomical marks used in the analyses.

The shape is defined in the morphometrical analysis based on the configurations of points that alter in terms of size, position and direction in the wing (MonTEIro \& ReIS, 1999). Shape asymmetry was obtained in the overlapping method of Procrustes (KLingenberg \& McInTYRe, 1998; Monteiro \& Reis, 1999).

The data obtained in TpsDIG2, which represent the position of coordinates of each anatomical point in a Cartesian plan, were taken to the MorphoJ program for the morphometrical analysis. These data allowed to perform the processes of overlapping (translation), proportion and rotation. The generalized adjustment of Procrustes is conducted as reference to the average configuration to obtain the "consensus". Therefore, the final configurations of the aligned species constitute a group of variables that refer only to the shape of structures (Monteiro \& ReIs, 1999).

The generated consensus comprises a group of average positional values of the anatomical points for each wing and pollen basket of A. mellifera for each population and is represented simultaneously as "consensus wing" and "consensus pollen basket".

Multivariate statistical analysis of the data included the Canonic Variables Analysis and grouping analysis were used in the Mahalanobis $\mathrm{D}^{2}$ distance. The Mahalanobis $\mathrm{D}^{2}$ distance between the centroids of the morphometrical data on each location was used as a measurement of the morphometrical distance (MANLY, 1991). The matrix of distance $\mathrm{D}^{2}$ was used for the grouping analysis by the method Unweighted PairGroup Method using an Arithmetic Average (UPGMA), in which the intergroup distance was obtained by the average of the paired distances of the members of the two groups, as described in DiAs (1998).

The Canonic Variables Analysis (CVA) was, then, performed using the averages of the populations obtained in the morphometrical analyses in order to verify the differences among the populations collected in the five regions of the country.

Afterwards, the analysis of cross validation was conducted to measure data accuracy and the correct assignment percentages of individuals in their respective locations. The analyses were carried out using the PAST and $\mathrm{R}$ programs, respectively.

\section{RESULTS AND DISCUSSION}

The analyses on the population of A. mellifera using the wings morphometry showed that after the sixth canonic variable, it was possible to explain around $76 \%$ of the total variation of the populations studied. This allows to state that the A. mellifera is a species capable of establishing efficiently in different regions for its fast development and easy adaption. In addition, its wide distribution allows to maintain a pollen pool (DALY \& BALLING, 1978; DinIz-Filho et al., 2000) turning the individuals similar to one another.

In the analyses of morphometrics divergence, the configuration of the groups distribution was represented by a two-dimensional space to facilitate the visualization of the similarities in the colonies, defined by two canonic vectors (Fig. 3), using the scores of the canonic variables (canonic average) obtained from the first two canonic variables.

The graphical analysis for the standard study of similarity between the colonies allows to verify the proximities and distances of each colony and to observe the total variation available using a few variables which, according to CRUZ \& CARNEIRO (2003), it is important for the analysis of morphometrical diversity through the graphic dispersion in relation to axes represented by the canonic variables.

The multivariate analysis (MANOVA) was significant $(p>0.001)$ for the wing and pollen basket shapes in the comparative analysis among colonies. Studies carried out by TAN et al. (2006) demonstrated a great variation in the morphometrical characteristics in bees $A$. cerana in China, varying in size, pigmentation and hairiness associated to the ecological diversity in China. DinIz-FilHo et al. (2000) observed significant variations of subspecies of $A$. mellifera among local populations in 


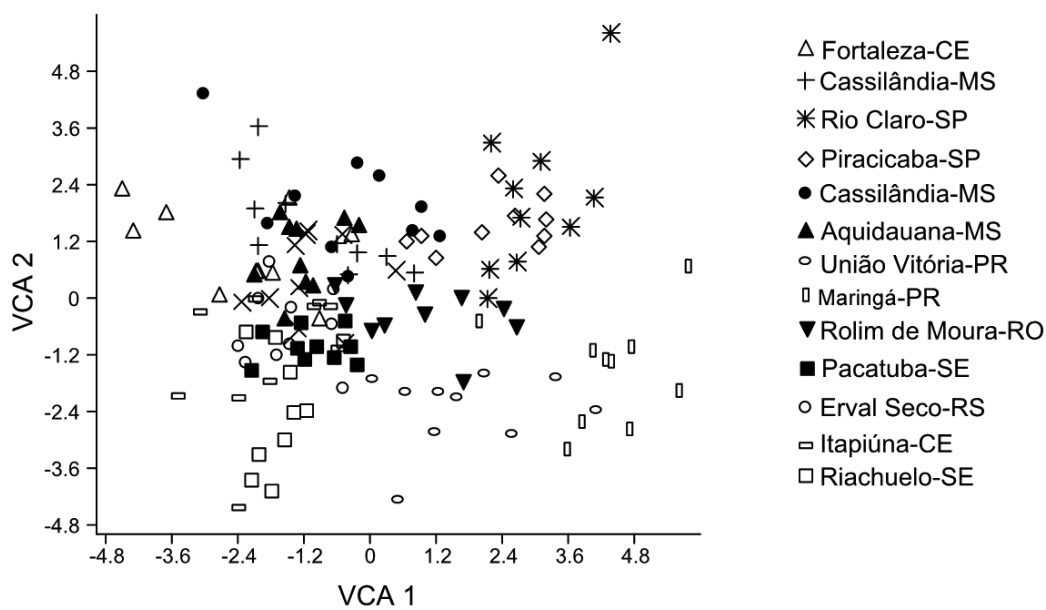

Fig. 3. Graphical dispersion of the Apis mellifera colonies in relation to the Cartesian axis established by the canonic variables (VCA 1, VCA 2) obtained from the wings morphometry.

Africa characterized by its wide distribution in different vegetations and climate. We found similar results in this study where different geographic regions showed distinct types of vegetation and climate. GüLER et al. (2010) observed high variability between the subspecies Apis mellifera carnica and A. mellifera caucasica using geometric morphometrics of the front wing to evaluate different ecological regions, showing the efficiency of the method to assess population differences.

We verified the formation of distinct groups per region in the grouping analysis UPGMA (Fig. 4) based on the CVA, according to the geographical distribution of colonies (Fig. 5).

As observed by TofiLsky (2008), the geometric morphometrics is a technique suitable to identify variations of $A$. mellifera, besides presenting more facility to interpret data comparing with many distances measured, the asymmetric grades identify the wing region that mostly contributes to the variation.

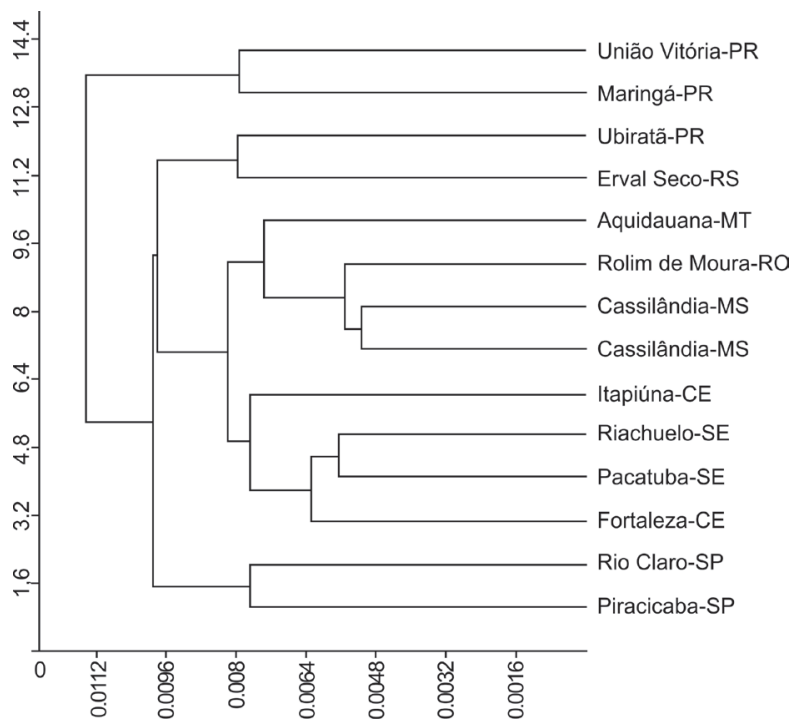

Fig. 4. Dendrogram generated by UPGMA illustrating the average morphometrical distances among the colonies of Apis mellifera from different locations in the five regions of Brazil.
We carried out the crossed validation with the data on the front wings to verify the classification percentage of individuals within each group and we obtained $62 \%$ of correct identification. It shows that although the populations differed per region, the phenotypic features still do not show a well-defined pattern throughout Brazil and the similarities between individuals of $A$. mellifera may be influenced by agricultural practices such as migratory apiculture, contributing to the genetic derivation with the introduction of new bees, altering the analyses in a wide geographical scale (Diniz-Filho $\&$ Malaspina, 1995). Besides the migratory condition of colonies, apiarists commonly trade the queen bee, which may have contributed to some population similarities found in A. mellifera bees in Brazil.

In the population analysis using the pollen baskets of A. mellifera, the CVA was significant in a way that the second variable already accumulates $85 \%$ of the total variation, where the first canonic variation explains $75 \%$ and the second $10 \%$ of the total variation. Although the CVA analysis is representative with the first two variables for the pollen basket shape, the analysis of crossed validation with the pollen baskets allowed to verify a percentage of $11.8 \%$ of the individual correct classification within each group. The CVA analysis shows that pollen basket shape does not display significant differences enough to form distinct groups in the populations studied. These results suggest that the pollen basket have more restrictions of shape variation that can be explained by the important role of the pollen basket shape in the pollination process, however, the fact that this structure did not show significant differences may also be attributed to the small number of anatomical marks.

The richness of the spatial structure indicates the diversity of the micro-evolutionary processes acting in the population differentiation, however, the difficulty to determine this process in detail is clear, due to the few characters that present complex spatial patterns. This complexity and mix of processes are in fact expected 


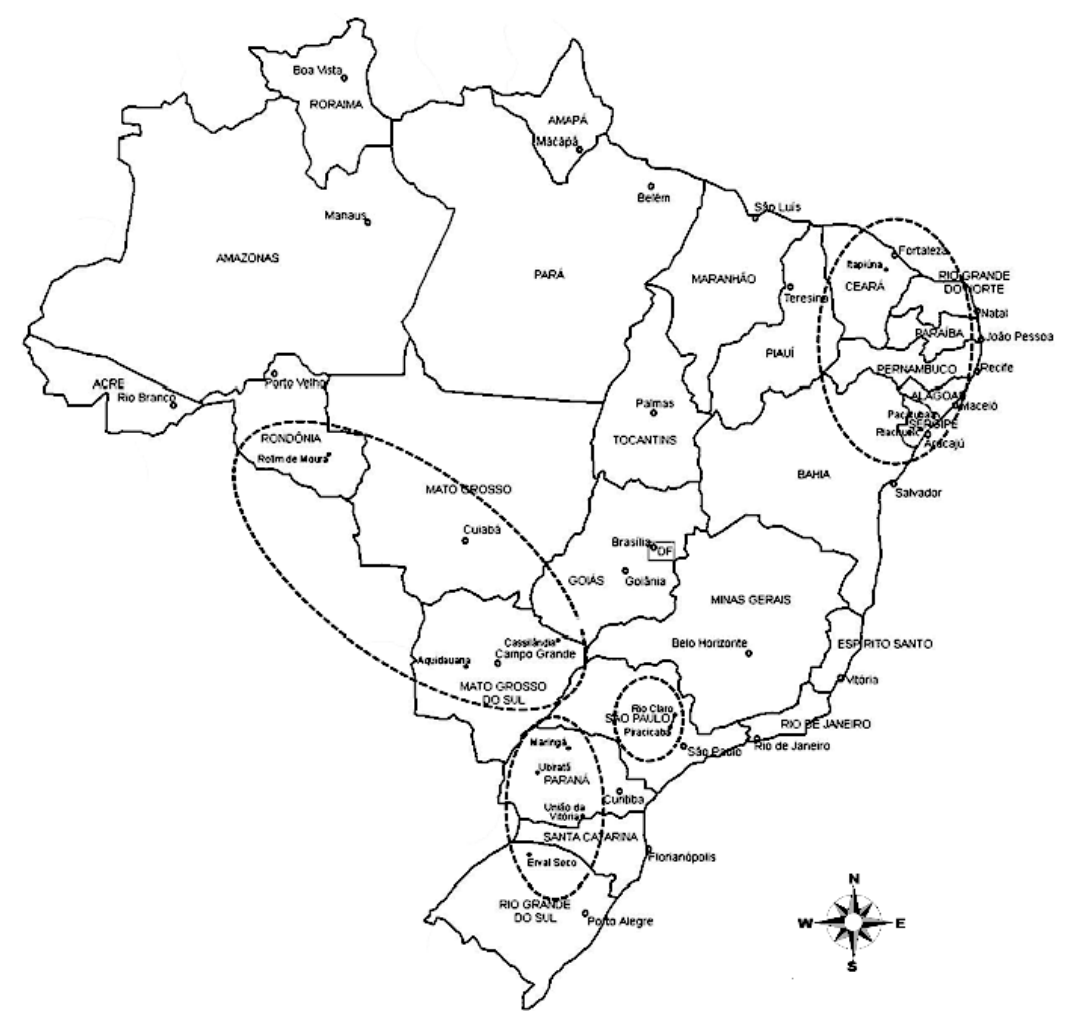

Fig. 5. Graphical representation of the grouping generated by UPGMA in Brazil, demonstrating group formations in the different regions.

for the natural populations of African bees, along the period of time that the natural population needs in stochastic processes such as isolation of local driftage by the distance and by the different selective agents acting throughout the continent with different scales of variation in time and space (DINIZ-FiLHo et al., 2000). SouzA et al. (2009) verified the formation of two distinct groups in populations of $A$. mellifera for the different geomorphologic regions existing among individuals assessed in the state of Paraíba, Brazil.

Our results show that the distribution and predominance of the bees in Brazil suffered the "Africanization" process. Similarly, DinIz-FILHO \& MALASPINA (1995) observed that the morphometrical data on Africanized bees in Brazil indicate predominance of a African component in the populations of Apis mellifera in the country, which was also observed in several previous studies. The authors corroborate that the Africanized bee in Brazil originates from a hybridization during the initial colonization of the African bee, forming many populations with distinct levels of hybridization between the African and European bees.

The genetic pool of the African bees has high viability and fertility, therefore, a high capacity of colonization in tropical and subtropical environments (RATNIEKS, 1991). Moreover, the hybrids with a high African component and associated to this capacity of colonization show a quick dispersion and population growth, besides the migratory feature, which contributes to the maintenance of a strong African component (DinIZFilho \& Malaspina, 1995; Garcia \& Couto, 2005).
In the expansion process, the bees may have formed a gradient in which the populations show different levels of losses of the European feature acquired during the initial phase of the hybridization. This loss may have been caused by greater selective pressure in favor of the African pool existing in the colonization (RATNIEKS, 1991). Species from Africa show common features of adaptability, foraging crepuscular activity, capacity to inhabit open places, migrations to regions rich in food sources, strategies to escape from predators with fast flights and minimization of vacant periods in the hive without a queen (FLETCHER, 1978).

Finally, 16 years after the morphometrical study carried out by Diniz-Filho \& MALASPINA (1995) on A. mellifera and with the intensification of the "Africanization" process of A. mellifera in Brazil, its distribution and facility to nest, we can still verify that this species has morphometrical differences based on the wing morphometry, presenting a geographical pattern per region. These results corroborate DinIZ-FILHO et al. (2000), who observed that population similarity decreases with the increase of the geographic distance. These differences may be associated to diversified vegetation, the different types of climate and topography in the country (IBGE, 2004), besides the fact that the country has a large territorial area, allowing the microevolutionary processes to act in different bioregions generating new differentiation patterns, therefore, promoting the "Africanization" wave.

In this study, the comparison of A. mellifera populations was performed using the geometric 
morphometrics, differently from the work conducted by Diniz-Filho \& Malaspina (1995) who used traditional morphometrics, because according to ROHLF \& MARCus (1993), the new morphometrical approaches are more effective to capture data on the shape of an organism, which result in better statistical procedures. Moreover, they allow the researcher to visualize shape differences, distance measurements using the coordinates and carry out univariate and multivariate statistical analyses. The traditional morphometrics does not allow to verify shape variations as a data matrix of distance measurements and the results are demonstrated only numerically.

Acknowledgements. We thank Prof. Dr. Leandro Rabello Monteiro (UENF) for helpful discussions and suggestions and we wish to thank the Fundação de Amparo à Pesquisa do Estado de São Paulo (FAPESP) and Conselho Nacional de Desenvolvimento Científico e Tecnológico $(\mathrm{CNPq})$ for the financial support. We also thank the apiarists for supplying the biological material for the study.

\section{REFERENCES}

Bitner-Mathé, B. C.; Peixoto, A. A. \& Klaczko, K. L. B. 1995. Morphological variation in a natural population of Drosophila mediopunctata: altitudinal cline, temporal changes and influence of chromosome inversions. Heredity 75:54-61.

Cruz, C. D. \& Carneiro, P. C. S. 2003. Modelos Biométricos aplicados ao melhoramento genético. Viçosa, Universidade Federal de Viçosa. 585p.

Daly, H. V. \& Balling, S. S. 1978. Identification of Africanized Honeybees in the Western Hemisphere by Discriminant Analysis. Journal of the Kansas Entomological Society 51(4):857-869.

Dias, L. A. S. 1998. Análises multidimensionais. In: Alfenas, A. C. ed. Eletroforese de isoenzimas e proteínas afins. Viçosa, Universidade Federal de Viçosa, p. 405-473.

Diniz-Filho, J. A. F. \& Malaspina, O. 1995. Evolution and population structure of Africanized honey bee in Brazil: Evidence from spatial analysis of morphometrical data. Evolution 49(6):11721179.

Diniz-Filho, J. A. F.: Hepburn, H. R.; Radloff, S. \& Fuchs, S. 2000. Spatial analysis of morphological variation in African honeybees (Apis mellifera L.) on a continental scale. Apidologie 31:191-204.

Fletcher, D. J. C. 1978. The African bee, Apis mellifera adansonii in Africa. Annual Review of Entomology 23:151-171.

Francoy, T. M. \& Imperatriz-FonseCA, V. L. 2010. A morfometria geométrica de asas e a identificação automática de espécies de abelhas. Oecologia Australis 14(1):317-321.

Francoy, T. M; Prado, P. R. R.; Gonçalves, L. S.; Costa, L. F. \& De JoNG, D. 2006. Morphometric differences in a single wing cell can discriminate Apis mellifera racial types. Apidologie 37:91-97.

Francoy, T. M.; Wittmann, D.; Drauschke, M.; Müller, S.; Steinhage, V.; Bezerra-Laure, M. A. F.; De Jong, D. \& Gonçalves, L. S. 2008. Identification of Africanized honey bees through wing morphometrics: two fast and efficient procedures. Apidologie 39:1-7.

Friess, M. \& BAYlaC, M. 2003. Exploring Artificial Cranial Deformation Using Elliptic Fourier Analysis of Procrustes Aligned Outlines. American Journal of Physical Anthropology 122:11-22.

Garcia, R. C. \& Couto, R. H. N. 2005. Produção de geléia real por abelhas Apis mellifera italianas, africanizadas e descendentes de seus cruzamentos. Acta Scientiarum, Animal Sciences 27(1):1722.

GonçaLVES, L. S. 2006. Meio século de Apicultura com abelha Africanizada no Brasil. Available at: <http://www.apacame.org. $\mathrm{br} /$ mensagemdoce/87/artigo.htm $>$. Accessed on: 17.11.2011.

GÜLER, A.; BEK, Y. \& GUVEN, H. 2010. The importance of morphometric geometric on discrimination of carniolan (Apis mellifera carnica) and caucasian (Apis mellifera caucasica) honey bee subspecies and in determining their relationship to thrace region bee genotype. Journal of the Kansas Entomological Society 83(2):154-162.

IBGE. 2004. Mapas de Biomas e Vegetação. Available at: $<$ http://www. ibge.gov.br/home/presidencia/noticias/21052004biomashtml. shtm>. Accessed on: 17.11.2011.

KlingenBerg, C. P. 2002. Morphometrics and the role of the phenotype in studies of the evolution of developmental mechanisms. Gene 287:3-10.

Klingenberg, C. P. \& McIntyre, G. S. 1998. Geometric morphometrics of developmental instability: analyzing patterns of fluctuating asymmetry with Procrustes methods. Evolution 52:1363-1375.

Manly, B. F. J. 1991. Randomatization and Monte Carlo methods in biology. London, Chapman and Hall. 281p.

Michener, C. D. 1975. The Brazilian bee problem. Annual Review of Entomology 20:399-416.

Monteiro, L. R. \& Reis, S. F. 1999. Princípios de morfometria geométrica. Ribeirão Preto, Holos. 188p.

Monteiro, L. R.; Diniz-Filho, J. A. F.; Reis, S. F. \& Araujo, E. D. 2002. Geometric estimates of heritability in biological shape. Evolution 56(3):563-572.

Nunes, L. A.; Araujo, E. D.; Carvalho, C. A. L. \& Waldschmidt, A. M. 2008. Population divergence of Melipona quadrifasciata anthidioides (Hymenoptera: Apidae) endemic to the semi-arid region of State of Bahia, Brazil. Sociobiology 52:81-93.

Pretorius, E. 2005. Using geometric morphometrics to investigate wing dimorphism in males and females of Hymenoptera - a case study based on the genus Tachysphex kohl (Hymenoptera: Sphecidae: Larrinae). Australian Journal of Entomology 44:113-121.

RatnieKs, F. L. W. 1991. Africanized bees: Natural selection for colonizing ability. In: M. SPIVAK; Fletcher, D. J. C. \& Breed, M. D. eds. The "African" Honey Bee. San Francisco, Westview Press, p. $119-136$

RoHLF, F. J. 1998. On applications of geometric morphometrics to studies of ontogeny and phylogeny. Systematic Biology 47:147158.

RohlF, F. J. \& Marcus, L. F. 1993. A revolution in morphometrics. Trends in Ecology and Evolution 8:129-132.

Shipunov, A. B. \& Bateman, R. M. 2005. Geometric morphometrics as a tool for understanding Dactylorhiza (Orchidaceae) diversity in European Russia. Biological Journal of the Linnean Society 85:1-12

Souza, D. L.; Evangelista-Rodrigues, A.; Ribeiro, M. N.; PadillaÁlvarez, F.; Farias, E. S. L. \& Pereira, W. E. 2009. Análises morfométricas entre Apis mellifera da microrregião do sertão Paraibano. Archivos de Zootecnia 58(221):65-71.

Tan, K.; Meixner, M. D.; Fuchs, S.; Zhang, X.; He, S.; Kandemir, I.; Sheppard, W. S. \& Koeniger, N. 2006. Geographic distribution of the eastern honey bee, Apis cerana (Hymenoptera: Apidae), across ecological zones in China: morphological and molecular analysis. Systematics and Biodiversity 4(4):473-482.

THORP, R. W. 1979. Structural behavioral and physiological adaptation of bee (Apoidea) for collecting pollen. Annals of the Missouri Botanical Garden 66:788-812.

TOFILSKY, A. 2008. Using geometric morphometrics and standard morphometry to discriminant three honeybee subspecies. Apidologie 38:538-563.

Winston, M. L. 2003. A biologia da abelha. Porto Alegre, Magister. 256p.

Recebido em 29 de maio de 2012. Aceito em 19 de julho de 2012. ISSN 0073-4721

Artigo disponível em: www.scielo.br/isz 